\title{
Conduct code mooted for bioweapons treaty
}

Natasha McDowell, London

A code of conduct for scientists could help to strengthen the international Biological and Toxin Weapons Convention (BTWC), according to Britain's Royal Society.

Negotiations aimed at reviewing the 1972 convention broke down last December, when the United States blocked plans to allow laboratory inspections as a means for checking compliance with the BTWC (see Nature 414, 675; 2001).

The British government floated the idea of a code of conduct earlier this year as a way to strengthen the BTWC even if the United States maintains its position. The Royal Society's endorsement of the proposal, contained in a report released on 6 November, comes as negotiations on the convention resume this week in Geneva.

The report argues that there is considerable ignorance of the BTWC among British researchers, and that a code of conduct would encourage all scientists to consider the biowarfare applications of planned research.

The society did not give details of a code, but noted that some institutions have already developed their own rules. Some, for example, require researchers to assess biowarfare applications of their work formally before beginning a project.

The need for such formal assessments was highlighted last January, when Australian researchers working on a contraceptive vaccine for rodents inadvertently created a highly virulent strain of mousepox (see Nature 411,232-235;2001).

Brian Spratt, a molecular biologist at Imperial College in London and a member of the committee that compiled the report, believes that the code of conduct could be incorporated into existing mechanisms. Many universities have safety committees that assess the risk of experiments such as creating strains of genetically modified crops, for example. Spratt says that the same committees could also consider biowarfare implications of proposed research. A professional body within each country with the ability to dole out sanctions could be another enforcement mechanism, the report's authors say.

In addition to the code of conduct, the report recommends that biowarfare issues should be introduced into academic courses. And it calls for an international scientific advisory panel to monitor new developments regularly, in an effort to keep up with the rapid progress in biological technologies.

"It would mean that advances could be kept under international review in a more systematic way than at present," says Brian Eyre, a materials scientist at the University of Oxford, who chaired the committee.

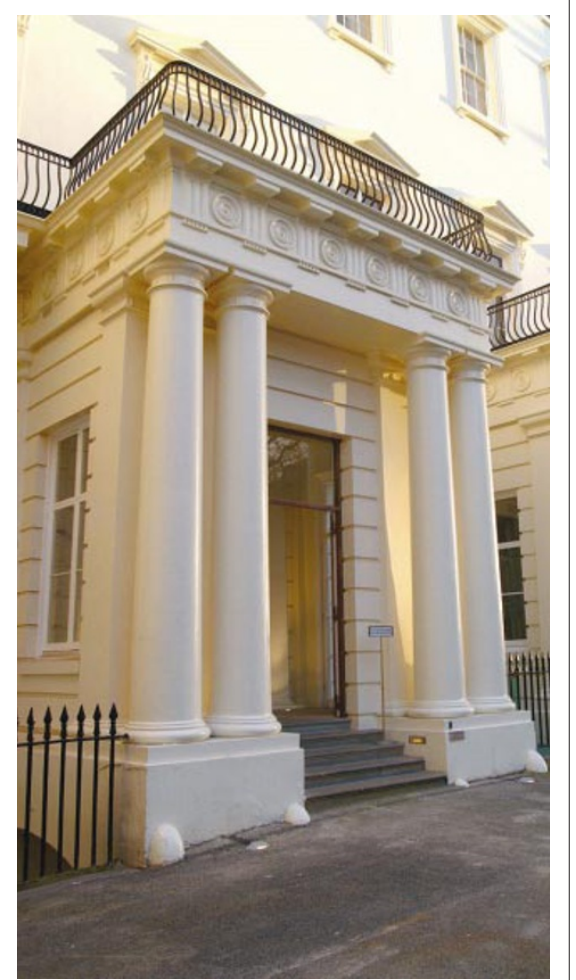

Pillars of society: the Royal Society wants to see education about potentially dangerous research.

\section{Academy slams Internet arts and sciences lookalike}

\section{David Adam, London}

Researchers may do well to heed Groucho Marx's comment: “I don't want to belong to any club that will accept me as a member."

Two weeks ago Nature revealed that the self-styled European Academy of Sciences appears to have no high-brow status (see Nature 419, 865; 2002), despite grandiose claims made to scientists invited to become members. Now, it seems, a similar academy has emerged across the Atlantic.

Over the past few months, the North American Academy of Arts and Sciences not to be confused with the American

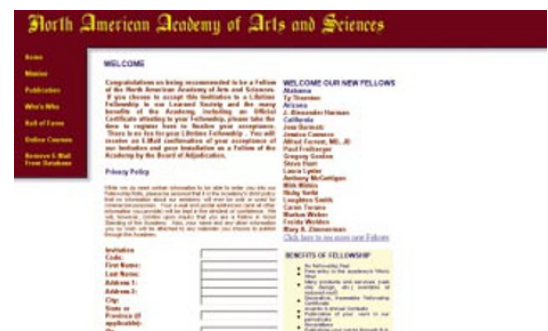

Academy awards: "If you choose to accept this invitation" - you will be in colourful company.
Academy of Arts and Sciences, which is based in Cambridge, Massachusetts - has bulk-distributed e-mails to researchers, inviting them to become members.

Membership and its 'benefits' — such as the opportunity to publish in the academy's journals - are free, although members are encouraged to send off $\$ 20$ for a certificate. On its website the academy claims to offer scholarships and awards, and to organize conferences and contests. It laments that "all too often, those who make the greatest contribution to our society go unrecognized".

But Nature has been unable to find any record of the academy's publications, awards or conferences, or to contact its organizers. No names appear on any of its e-mails or on its website, which is registered to a postal address in Budapest, Hungary. Enquiries sent to several of the academy's listed e-mail addresses went unanswered.

The American Academy of Arts and Sciences says it has had the website closed down several times, only to see it spring up again. It is now considering legal action.

Many scientists have become members of the self-styled "learned society", according to its website, joining a feng shui expert, a hypnotherapist and a town crier. Computer scientist Kia Ng, of the University of Leeds, UK, says he knows little about the academy, but joined "because it only involved clicking a link". He has not bought a certificate.

"It is nice to say you are a member, especially if you don't pay anything," says Dragan Cisic, a researcher in maritime studies at the University of Rijeka, Croatia.

Others say that their names are being used without their knowledge. Hossein Arsham, a statistician at the University of Baltimore, Maryland, is listed as a member, but says that he has never heard of the academy and that its information about him is years out of date.

The academy offers its fellows the opportunity to make money by writing exam questions for an online certification programme, to be offered through the "New York College of Advanced Studies". The college's website, which gives no details of its accreditation or organizers, says that for "three easy payments of US $\$ 21$ ", students will be able to take tests and receive certificates from the college, described as an affiliate of the academy. 